\title{
DEVELOPMENT AND IMPLEMENTATION OF IDEAS OF LIFELONG LEARNING IN EUROPE AT THE DAWN OF THE 21ST CENTURY
}

\author{
ALEKSANDRA MARCINKIEWICZ-WILK \\ Faculty of Pedagogy, University of Wrocław, \\ ul. J. W. Dawida 1, Wrocław, Poland \\ E-mail address: aleksandra.marcinkiewicz-wilk@uwr.edu.pl \\ EWA JURCZYK-ROMANOWSKA \\ Faculty of Pedagogy, University of Wrocław, \\ ul. J. W. Dawida 1, Wrocław, Poland \\ E-mail address: ewa.jurczyk-romanowska@uwr.edu.pl
}

\begin{abstract}
Aim. The aim of article is to present the changing of idea of lifelong learning. The article focuses on the idea of lifelong learning. The first part shows the essence of lifelong learning. An attempt has been made to organise concepts such as lifelong learning, lifelong training, continuing education and permanent education, as well as education and adult education, to consequently educe the idea of lifelong learning from the concept of continuing education.

Methods. The method used is the literature analysis because of the theoretical character of a paper.

Results. In the paper, it is presented how idea of lifelong learning was changing over time. Furthermore, the article shows the social context of the use of lifelong learning in relation to the theory of human capital and social capital theory as well. The next part of the article concentrates on identifying the most important initiatives of the European Union, the objective of which is the implementation of the idea in Europe. The article presents the aims of the EU programmes that are focused on the implementation of that idea in European education.

Conclusions. The development of the idea of lifelong learning is related to a social and cultural changes. This idea is a very important part of EU strategy, which main gol is to build the Information Society.

Key words: lifelong learning, permanent education, European Union policy, adult
\end{abstract} education.

\section{SUBSTANCE OF LIFELONG LEARNING}

Education in the modern world has become an integral part of life, allowing for easier operation in the new reality. Nowadays we can also meet with 
the opinions that lifelong learning is no longer a voluntary educational activity undertaken by a privileged part of society, but an absolute compulsion and necessity to proper functioning the proper functioning in the wider world (Malewski, 2001, p. 37).

The new educational reality is bound up with the idea, according to which the learning process is extended to the whole of human existence. It is the basis for the emerging information society. The lifelong education is not a new idea, since in 1926, Eduard Lindeman, in his work The Meaning of Adult Education, developed the thesis that claimed that education is a continual learning process, and so it should continuously last for a lifetime (Lindeman, 1926).

In the literature the terms lifelong learning, lifelong training, continuing education and permanent education are used interchangeably. Mieczysław Malewski pointed out this conceptual chaos in andragogy (Malewski, 2001, pp. 29-30). Józef Kargul saw reasons for this conceptual chaos, among other things, in inaccurate translation of foreign-language texts into Polish (Kargul, 2001, pp. 38-40). However, the reason is not sufficient, because there can also be seen terminological inaccuracies within lifelong learning in English literature, which has been recognised by, among others, John Field (2004, pp. 2-3) or Peter Jarvis (2004). However, the decision concerning the terminology of lifelong learning should be done in the context of andragogy, as this idea has its origin in adult education, as earlier indicated.

Adult education can be called a phenomenon of the last century. Thanks to the conferences organised by UNESCO, the issue of adult education has been noted by researchers, who initiated research in this area. Reasons for the sudden interest in adult education can be traced to social changes and the changing perceptions of humans and their relation to society (Malewski, 2010, p. 46). In the past school education provided knowledge, skills and action patterns to an individual, which worked well and were sufficient for the whole of his or her life (Mead, 2000, pp. 106-147). The development of industrial centres, and thus increase in employment of people in this sector resulted in new educational needs. Technical skills became crucial as they translate into higher productivity.

Initially, adult education, in addition to that was focussed on interaction with the adult learner; in essence, its form and methods did not differ significantly from the education of children. It was limited primarily to further education, the aim of which was to enable human adults to resume education anew or to supplement it. All in all, it fulfilled a compensation and revitalisation function. There was a greater focus on formal education, and therefore one that takes place in educational institutions (schools), while disregarding the importance of informal and non-formal education (Malewski, 2010, p. 49).

Józef Półturzycki pointed out that the term "adult education" referred to the spreading of knowledge among people. For this reason, it is more reasonable to use the term "education for adults," which "means mental training of the adults, high school education and higher education" (Półturzycki, 1994, pp. 18-19). Similarly, Peter Jarvis distinguished between the terms of "adult 
education," which can be translated as "adult education" or "adult training" and "education for adults," which was understood as the development of existing knowledge of adults and ability to develop their interests in their spare time. It was a liberal form of education in which it was assumed that human learning has already been completed, and these actions are merely a continuation of initial education. The term "education of adults" refers to any "educational process undertaken by adults- liberal, general, or professionalwhich takes place in adult education, further education, higher education, or outside the institutional framework. This term also means that education is not complete at any stage of life, since education of adults may start both during school education (formal), and after the completion of formal"1 ${ }^{1}$ or "compulsory education" (Jarvis, 2004, pp. 44-46). This approach gave an impulse to the widespread idea of continuing education, which emphasising the aspect of non-formal adult education.

At the beginning continuing education referred to the improvement of people professionally active. Development of this position was to create a concept, according to which continuing education includes all areas of adult education, which clearly separated continuing education from youth education and education in the family and the environment as well. Another theory puts pressure on the permeability of the school system, as a system of continuous education considered as further education: vocational education, higher education and postgraduate studies (Półturzycki, 2004, p. 36).

\section{LIFELONG LEARNING AND THE CONCEPTS OF HUMAN AND SOCIAL CAPITAL}

The causes of andragogy's interest in the concept of lifelong learning can be traced to human capital theory, which states that investment in education remains in link with the pace of socio-economic development of a society and individual development. As part of the human capital theory, there are two currents of thought. The first one functions as the idea of human resources development. Scientific investigations were carried out in the macro-structural perspective and included research and economic analysis. Man was reduced to being referred to as homo economicus. Just as natural resources were treated as economic capital, which is also renewable and virtually unending. This concept ignores the importance of personality, social and cultural dimensions of education, reducing it to only economic value. However, research in this area showed that the results differ significantly from the theoretical assumptions. Even if there is a correlation between education and social development, it would not assume a linear form (Malewski, 2010, pp. 49-53).

On the other hand, the second trend of studies, the most commonly adop-

1 The author uses the term initial education, which must be understood not as initial education, and therefore one that takes place in primary school, but as a formal education, so from primary school up to university degree (Jarvis, 2004, pp. 44-46). 
ted by andragogy, was conducted in the microstructural perspective and included research on democratic citizenship. This trend, in contrast to the former one, is associated with the non-economic benefits. It assumes that due to the multiple layers of reality and emergent nature of these layers, a person can only affect microstructural level of social life. Thus, local adult education is the most effective tool for shaping social life (Malewski, 2010, pp. 53-54).

Not without significance for the popularisation of the lifelong learning were also socio-economic changes. Moving away from mass production, as well as a growing sphere of services, implied the need for a new type of competence. "Hard" technical qualifications that are adequate to the realities of industrial society yield to "soft" interpersonal and organisational qualifications, which respond more appropriately to the reality of the post-industrial reality. New educational requirements revealed the inadequacy of formal education. Continuing education, which moved the stress from institutional education (formal) to non-formal education, was a response to these changes.

In the 1980's the concept of continuing education was transformed into the idea of lifelong learning. The sources of popularisation of the idea of learning throughout life can be traced in the theory of social capital. This theory, similarly to the theory of human capital, refers to the theses that the key factors in development are knowledge and skills; nevertheless, it puts the emphasis on the socio-cultural context of human competence. The concept of social capital is treated as a humanised version of the theory of human capital (Malewski, 2010, p. 56-57). "Devoid of the characteristic of its predecessor technocratic perspective, it operates »soft « variables - trust, the quality of social relationships, ability to self-organise and cooperate in society, and even the mentality of individuals. They create a socio-cultural context and a particular social climate that determines to what extent people's powers of enforcement can translate into development and progress" (Malewski, 2010, p. 57).

Education becomes an inseparable part of human life and constitutes social interactions. It ceases to be only an activity taking place in institutions, and becomes an "integral part, a kind of dialectic game between the knowledge, experience and action. Its aim is the reflective interpretation of the components of the world of life and the redefinition of the identity of the learning subject" (Malewski, 2010, p. 58).

The most complete scope of the concept of lifelong education was adopted by UNESCO, according to which the essence of education covers the whole life of an individual and serves its development. It is also the guiding principle that indicates the direction of modern general education reforms, as well as vocational and higher education, vocational training, adult education, parallel education and education in the family and in the environment.The main tasks of continuing education are seen in the upbringing of new types of humans, characterised by a creative attitude and a dynamic attitude to life and culture - capable of improving themselves, of changing living conditions and improving them (Półturzycki, 2004, p. 36). Such an understanding of lifelong learning is recognised by scientists in Poland, Scandinavia, France and America, 
although there are still attempts to identify continuing education with vocational development or adult education.

\section{THE IMPLEMENTATION OF THE IDEA OF LIFELONG LEARNING IN THE EUROPEAN UNION AT THE BEGINNING OF THE XXI CENTURY}

In the face of radical economic and social change, due to which the problems associated with the ageing of the population are felt even more strongly, the European Union decided to build an information society. Therefore, it was decided to implement the socio-economic reform plan contained in the Lisbon Strategy (compare: Kobylarek, 2008, pp. 83-93). This made the idea of lifelong learning one of the main priorities of the United Europe, as reflected in $A$ Memorandum on Lifelong Learning (Commission of the European Communities, 2000), and published a year later in the European Commission Communication Making a European Area of Lifelong Learning a Reality (Commission of the European Communities, 2001).

This memorandum marked the beginning of a Europe-wide debate on a strategy, which aim would be the implementation of lifelong learning in all spheres of public and private life. It was indicated in the above document that lifelong learning should be the guiding principle in education, thus providing all EU citizens equal access to all forms of education. The result of the consultation launched by the memorandum was the already mentioned Communication Note, which adopted the definition of lifelong learning as "all forms of learning undertaken throughout life, in order to deepen the knowledge, skills and competences in an individual, civic, social and/ or professional context" (Commission of the European Communities, 2001). Lifelong learning involves, therefore, active citizenship, social integration, self-realisation, and labour market support. The European Commission drew attention to the central place of the student in the educational process, which corresponds to a humanist educational work model with an adult, to which non-formal education is attributed. This is an example of shifting the centre of gravity from formal education to non-formal education, as mentioned in the previous section.

Another important document for the development of the idea of lifelong learning in Europe was the Communication from the Commission on making the European area of lifelong learning a reality (Commission of the European Communities, 2001). It included a series of priority actions to be taken to implement the concept of lifelong learning, and these relate to (Budzyńska, 2004):

- Creating a culture of learning by giving learning high significance. For this purpose it is advised: to increase the number of children covered by preschool education; to arouse a desire to learn from the early stages of education; to increase and diversify education at secondary education level; to adapt the offer of higher education to labour market needs; to 
develop a system of assessment and recognition of qualifications acquired in non-formal and informal learning; to develop and modernise adult education.

- Increasing public access to information and advice on learning opportunities through: raising the amount of guidance and easier access to information on learning opportunities in Europe; the development of cooperation between the public and private sectors in the field of vocational guidance; the development of services using ICT ${ }^{2}$ in guidance.

- Increasing investment (in terms of money and time) in learning through: increasing the scale of public and private investments aimed at human resources; the development of entrepreneurship by promoting initiative and creativity in the learning process; diagnosis of the factors that motivate people to learn; promotion of various educational paths; the development of open learning and distance learning, as forms of enabling people to combine learning with working and fulfilling their other obligations.

- Bringing educational opportunities closer through: supporting the development of local learning centres; providing learning opportunities for learners as close to their homes as possible; developing educational offer based on ICT.

- Dissemination of basic skills by: defining competencies and skills for the knowledge society; making efforts that compulsory education programs take into account the development of basic skills; ensuring that all groups and individuals, including those less advantaged, have opportunities to gain basic skills; taking measures to prevent learning failure; supporting and developing the so-called "second chance schools."

- Developing innovative educational concepts through: promotion and development of innovative forms of learning/teaching, especially those taking into account the use of ICT; preparation of educational opportunities (including the multimedia) that meet the needs of students, labour market, local or regional community and the whole society, while ensuring optimal use of resources.

These objectives reflect the vision of lifelong education which the EU wants to reach. Designated activities focus primarily on increasing the participation of people in education, by creating diverse educational offers and also making efforts towards the removal of barriers to participation in education . Learning should take place continuously from an early age and should take into account the basic competencies needed in the information society, including the ability to use ICT. The importance of informal and non-formal education was recognised. Confirmation of the above postulates of the European Commission was reflected in the Council Resolution on lifelong learning (The Council of the European Communities, 2002).

2 ICT - Information and Communication Technology. 
The idea of lifelong learning in the EU required the cooperation and coordination of various activities undertaken in this area at the European level. For this reason, it is worth pointing to two EU initiatives in context of education, which include the Bologna Declaration (The Bologna Declaration of June 19th, 1999...) - signed in 1999, which initiated the Bologna Process aimed at raising the prestige of European universities in comparison to the US universities by establishing a system of comparing degrees and academic titles. Another important initiative in this regard was the Copenhagen Process (Declaration of the European Ministers of Vocational Education and Training...), whose aim was to improve the results of the quality and attractiveness of vocational education and training through closer cooperation at European level. Both initiatives are part of the Single Strategy of Education and Training of the EU, known as the Education and Training 2010, announced in 2002. This program strengthened political cooperation in the context of education and training. This cooperation resulted in, among others, Lifelong Learning Programme- LLP 2007-2013. It was the second phase of the Union program in the field of education called Socrates.

The aim of the program was "to contribute, by learning throughout life, to the development of the Union as a knowledge-based society, characterised by sustainable economic development, growing number of better jobs and greater social cohesion, while ensuring proper protection of the environment for future generations. In particular, it aims to foster exchange, cooperation and mobility between education and training systems within the Union so that they become a world quality reference" (Official Journal of the European Union, 2006).

This initiative is related to the educational needs of all participants, as well as the institutions and organisations involved in education and training. All activities included mobility, languages and new technologies. The program consisted of three main sub-programs:

- sectoral programmes, which include four specific programs targeted at particular forms of formal and non-formal education;

- cross-sectoral programmes, which relate primarily to actions encroaching beyond the framework of sectoral programs. They include four key activities: strategic cooperation and innovation in terms of learning throughout life; promotion of foreign language learning; the development of innovation of the content, services, methodology of learning and practices based on the tele-informational technologies used for lifelong learning and the dissemination and use of results of actions taken within the program, including the exchange of good practices;

- Jean Monnet, which dealt with issues related to European integration in the academic world and the support needed by institutions and associations active in the field of education and training at European level. 
Table 1. Structure of the programme Lifelong Learning 2007-2013 LIFELONG LEARNING PROGRAMME - LLP

\begin{tabular}{|c|c|c|c|c|}
\hline \multirow[t]{2}{*}{$\begin{array}{l}\text { SECTORAL } \\
\text { PROGRAMMES }\end{array}$} & \multirow{2}{*}{$\begin{array}{l}\text { Comenius } \\
\text { School Education }\end{array}$} & \multirow{2}{*}{$\begin{array}{l}\text { Erasmus } \\
\text { Higher } \\
\text { Education }\end{array}$} & \multirow{2}{*}{$\begin{array}{l}\text { Leonardo da } \\
\text { Vinci } \\
\text { Training and } \\
\text { Vocational } \\
\text { Education } \\
\end{array}$} & \multirow{2}{*}{$\begin{array}{l}\text { Grundtvig } \\
\text { Adult Education }\end{array}$} \\
\hline & & & & \\
\hline $\begin{array}{l}\text { CROSS- } \\
\text { SECTORAL } \\
\text { PROGRAMMES }\end{array}$ & $\begin{array}{l}\text { Development } \\
\text { of educational } \\
\text { policy }\end{array}$ & $\begin{array}{l}\text { Foreign } \\
\text { language } \\
\text { learning } \\
\end{array}$ & $\begin{array}{l}\text { Development } \\
\text { of new } \\
\text { technologies }\end{array}$ & $\begin{array}{l}\text { Dissemination } \\
\text { of examples of } \\
\text { good practices }\end{array}$ \\
\hline \multicolumn{5}{|c|}{$\begin{array}{l}\text { PROGRAMME JEAN MONNET } \\
\text { The Jean Monnet programme stimulates teaching, research and reflection on European } \\
\text { integration at higher education institutions throughout the world. } \\
3 \text { key activities - Jean Monnet Action, European institutions, European associations }\end{array}$} \\
\hline
\end{tabular}

Source: based on: http://eacea.ec.europa.eu/llp/index_en.php.

The Lifelong Learning 2007-2013 programme was to carry out the tasks set by the Union in earlier initiatives, among others, in the Communication making a European area of lifelong learning a reality. Although after the completion of the program, significant progress in the implementation of the idea of lifelong learning was noted, it also recognised the enormity of the new tasks to be met. It is true that the EU Member States approve of the concept of lifelong learning and make efforts to make it a reality, nevertheless progress is far from sufficient. There is an apparent difference in the implementation of ideas between the countries which are "old" EU members and the new ones. Therefore, the Council of Europe decided to continue operations for the next 10 years and established a strategic framework for European cooperation in education and training (Strategic framework - Education E Training 2020), which uses the achievements of the earlier program. At the same time the program Lifelong Learning 2007-2013 has been replaced by the Erasmus+, which includes six sectors: school education, education and vocational training, higher education, adult education, youth education, central projects and sport.

In this program greater emphasis was put on formal and non-formal education, designed to develop the skills of students, teachers and staff and to improve their situation in the labour market ( $O$ programie Erasmus + ). There is a noticeable shift in the internal EU policy. In the current initiatives greater emphasis is put on innovation and supporting employment. On the other hand, the initiative Lifelong Learning 2007-2013 drew attention to measures aimed at preventing social marginalisation and building intergenerational dialogue. Currently, prevention of social exclusion is no longer a priority. This is all the more surprising that it was crucial for social cohesion and intergenerational learning.

Compared to the previous edition, the structure of Erasmus+ programme has been simplified and includes three main types of action:

Action 1: learning mobility (trips for educational purposes),

Action 2: cooperation for innovation and exchange of good practices,

Action 3: support for reforms in the field of education. 
The realisation of lifelong learning in the EU is not limited only to the aforementioned programmes as they are accompanied by a range of supportive initiatives. The strategy for the implementation of lifelong learning was outlined, which is reflected in strategic programs. As pointed out by Małgorzata Budzyńska, "the road to the actual implementation of that idea is long, while there still remains an imbalance between formal and informal education systems components" (2004).

European Union outlined the strategic areas, which are referred to vision adult education. Specific priorities for the period 2015 - 2020 are (Strategic framework - Education \& Training 2020):

- "Governance: ensuring the coherence of adult learning with other policy areas, improving coordination, effectiveness and relevance to the needs of society, the economy and the environment; increasing, where appropriate, both private and public investment.

- Supply and take up: significantly increasing the supply of high-quality adult learning provision, especially in literacy, numeracy and digital skills, and increasing take-up through effective outreach, guidance and motivation strategies which target the groups most in need.

- Flexibility and access: swidening access by increasing the availability of workplace-based learning and making effective use of ICT; putting in place procedures to identify and assess the skills of low qualified adults, and providing sufficient second-chance opportunities leading to a recognised EQF qualification for those without EQF level 4 qualifications.

- Quality: improving quality assurance, including monitoring and impact assessment, improving initial and continuing education of adult educators, and collecting the necessary data on needs to effectively target and design provision."

In accordance with these areas, the EPALE platform was created, which is a multilingual online space to exchange and promote methods of good practice in adult education.

It should be noted that making the idea of lifelong learning a reality was one of four strategic priorities described in 2009 as part of the assumptions Education and training 2020 (ET2020).

The degree of implementation of lifelong learning varies considerably from country to country. Countries that were already advanced in the implementation of education and vocational education reforms as well as those who had higher levels of investment in education take the most ambitious and significant initiatives. On the other hand, the second group of countries often has no developed mechanisms for coordination between ministries and integrated policy for lifelong learning (Budzyńska, 2004). It is a source of various degrees of implementation of the concept of lifelong learning.

It is worth noting that the potential of the idea of lifelong learning has been recognised by the European Union and a number of important initiatives in order to make it a reality has been taken. The Union actually sees education as a road to social and individual development. The main task of education is 
to equip the human being with essential competencies that take into account the specifics of the new reality, which is to guarantee the full participation in society for all.

\section{SUMMARY}

In the age of the emerging information society, learning is gaining more importance. In the face of ever-changing social reality, only a "learning" person is able to keep up with these changes. On the other hand, it should be emphasised that the goal of lifelong learning is not only focused on social participation, but also on the comprehensive development of an individual. Nevertheless, in the era of rapid social changes, the aspect of social participation is particularly emphasised.

The importance of lifelong education in the new reality was aptly captured by Katarzyna Druczak, according to whom: "learning is presented as a necessary condition for survival, as the biographical imperative in the world of voracious competition of economic uncertainty, instability and constant changes. Learning becomes a necessity enabling us to cope with a difficult, complex social reality. (...) I believe that the treatment of learning as a lifelong process, taking place in different social contexts, different real-life situations, allows living according to requirements and challenges of modern worlds" (2006, p. 35).

However, I understand the mere learning as Peter Jarvis does, as: "lifelong combination of processes, during which the whole person - body (genetic, physical, biological and abilities) and the mind (meaning, knowledge, attitudes, values, emotions, beliefs and senses) - experiences social situations, the content of which is then processed cognitively, emotionally or practically (or any combination thereof), and included in the personal biography of a person, which results in a constantly changing (or more experienced) person" (2012, p.11).

This definition indicates that learning is a process involving the whole person and what is more, it is a process that is strongly associated with the social world with which the "learning" man interacts.

\section{REFERENCES}

1. Budzyńska M. (2004). Koncepcja kształcenia ustawicznego w Unii Europejskiej jako jeden ze sposobów realizacji Strategii Lizbońskiej, ze szczególnym uwzględnieniem Polski [The concept of lifelong learning in the European Union as one of the ways to implement the Lisbon Strategy, with particular emphasis on Poland]. Urzad Komitetu Integracji Europejskiej. Retrieved from: http://www.dsw.edu.pl/fileadmin/user_upload/iped/materialy_dydaktyczne/Modele_ pracy_edukacyjnej/Lifelong_learning_artykul.pdf.

2. Budzyńska, M. (n.d.). Koncepcja ksztatcenia ustawicznego w Unii Europejskiej jako jeden ze sposobów realizacji Strategii Lizbońskiej, ze szczególnym uwzględnieniem Polski. Urząd Komitetu Integracji Europejskiej, Departament Analiz Ekonomicznych i Spotecznych. Warszawa. Retrieved December 10, 2017 from: http:/ / www.lifelong-learning.pl/unia/9.pdf.

3. Commission of the European Communities. (2000). Commission Staff working paper: A Memorandum on Lifelong Learning. Retrieved from: http://pjp-eu.coe.int/documents/1017981/1668227/ COM_Sec_2000_1832.pdf/f79d0e69-b8d3-48a7-9d16-1a065bfe48e5. 
4. Commission of the European Communities. (2001). Communication from the Commission of 21 November 2001 on making a European area of lifelong learning a reality [COM (2001) 678]. Retrieved from: http://eur-lex.europa.eu/LexUriServ/LexUriServ.do?uri=COM:2001:0678: FIN:EN:PDF.

5. Declaration of the European Ministers of Vocational Education and Training, and the European Commission, convened in Copenhagen on 29 and 30 November 2002, on enhanced European cooperation in vocational education and training "The Copenhagen Declaration" (n.d.). Retrieved December 10, 2017 from: http://ec.europa.eu/education/policy/vocational-policy/doc/ copenhagen-declaration_en.pdf.

6. Druczak, K. (2006). Znaczenie całożyciowego uczenia się w projektowaniu biografii przez osoby dorosłe [Importance of lifelong learning in design of biography by adults]. Dyskursy Młodych Andragogów , 7, 31-40.

7. Field, J. (2006). Lifelong learning and the new educational order. Stoke on Trent: Trentham Books.

8. Jarvis, P. (2004). Adult Education and Lifelong Learning. Theory and Practice. London-New York: Routledge.

9. Jarvis, P. (2012). Osobowe uczenie się: uczenie się w dziataniu [Personal learning: learning in action]. In: W. Jakubowski (Ed.), Kultura jako przestrzeń edukacyjna [Culture as an educational space] (pp. 9-25). Kraków: Oficyna Wydawnicza Impuls.

10. Kargul, J. (2001). Obszary pozaformalnej i nieformalnej edukacji dorostych. Przestanki do budowania teorii edukacji catożyciowej [Areas of non-formal and informal adult education. Premises for building the theory of lifelong education]. Wrocław: Dolnośląska Szkoła Wyższa Edukacji.

11. Kobylarek, A. (2008). Polskie kontrowersje wokót Procesu Bolońskiego [Polish controversy regarding the Bologna Process]. In: W. Bokajło, A. Wiktorska-Święcka (Eds.), Edukacja w Polsce wobec wyzwań konkurencyjności Unii Europejskiej [Education in Poland in the face of the competitiveness challenges of the European Union] (pp. 83-93). Wrocław: Oficyna Wydawnicza Atut - Wrocławskie Wydawnictwo Oświatowe.

12. Lindeman, E. C. (1926). The Meaning of Adult Education. New York: New Republic, INC.

13. Malewski, M. (2001). Edukacja dorosłych w pojęciowym zgiełku. Próba rekonstrukcji zmieniającej się racjonalności andragogiki [Adult education in a hustle and bustle. An attempt to reconstruct the changing rationality of andragogy]. Teraźniejszość-Człowiek- Edukacja, 2, 37.

14. Malewski, M. (2010). Od nauczania do uczenia się. O paradygmatycznej zmianie w andragogice [From teaching to learning. On the paradigmatic change in andragogy]. Wrocław: DSWE Wydawnictwo Dolnośląskiej Szkoły Wyższej Edukacji TWP.

15. Mead, M. (2000). Kultura i Tożsamość: Studium dystansu międzypokoleniowego [Culture and commitment: A study of the generation gap]. Warszawa: Wyd. Naukowe PWN.

16. O programie Erasmus + [About the Erasmus+ programme]. (n.d.). Retrieved December 10, 2017 from: http://erasmusplus.org.pl/o-programie/.

17. Official Journal of the European Union. (2006). Decision No. 1720/2006 / EC of the European Parliament and of the Council of 15 November 2006. Establishing an action program in the field of lifelong learning. Retrieved from: http://eur-lex.europa.eu/LexUriServ/LexUriServ. do?uri=OJ:L:2006:327:0045:0068:pl:PDF.

18. Półturzycki, J. (1994). Akademicka edukacja dorostych [Academic education of adult]. Warszawa: Wydawnictwa Uniwersytetu Warszawskiego.

19. Półturzycki, J. (2004). Szkolnictwo wyższe a idea edukacji ustawicznej [Higher education and idea of continuing education]. In: R. Górska, J. Półturzycki (Eds.), Edukacja ustawiczna w szkotach wyższych-od idei do praktyk [Continuing education at universities - from idea to practice] (pp. 36-52). Płock-Toruń: Wydaw. Instytutu Technologii Eksploatacji.

20. Strategic framework - Education \& Training 2020. (n.d.). Retrieved April 27, 2018 from: https:// ec.europa.eu/education/policy/adult-learning_en.

21. The Bologna Declaration of June 19th, 1999. - Joint Declaration of the European Ministers of Education (n.d.), [unpublished in the Official Journal]. Retrieved April 30, 2018 from: https:// www.eurashe.eu/library/modernising-phe/Bologna_1999_Bologna-Declaration.pdf.

22. The Council of the European Communities. (2002). Union Council Resolution of 27 June 2002 on lifelong learning, Official Journal of the European Communities, 163/01. Retrieved from: http:// eur-lex.europa.eu/LexUriServ/LexUriServ.do?uri=OJ:C:2002:163:0001:0003:EN:PDF. 